(2) Open Access Full Text Article

\title{
Perceived Quality of Healthcare and Availability of Supplies Determine Household-Level Willingness to Join a Community-Based Health Insurance Scheme in Amhara Region, Ethiopia
}

This article was published in the following Dove Press journal:

ClinicoEconomics and Outcomes Research

\author{
Asmamaw Atnafu (iD) \\ Amare Tariku ${ }^{2}$ \\ 'Department of Health Systems and \\ Policy, Institute of Public Health, College \\ of Medicine and Health Sciences, \\ University of Gondar, Gondar, Ethiopia; \\ ${ }^{2}$ Department of Human Nutrition, \\ Institute of Public Health, College of \\ Medicine and Health Sciences, University \\ of Gondar, Gondar, Ethiopia
}

Purpose: The Ethiopian health system has been challenged by a shortage of funds and is heavily reliant on foreign donation. However, voluntary community-based health insurance (CBHI) has been implemented to reach and cover the very large agricultural sector since 2010. Thus, the level of acceptability of the scheme needs to be regularly assessed through households' willingness to join before the nationwide rollout of the scheme. This study was intended to assess the level of willingness to join in community-based health insurance and associated factors in northwest Ethiopia.

Patients and Methods: Using a pretested structured questionnaire, a cross-sectional community-based study was conducted in 2017 in Amhara Region, northwest Ethiopia. Using a multi-stage sampling method, from 15 clusters in which CBHI was implemented, 1,179 households without CBHI membership were included as a sample for the study. Bivariable and multivariable logistic regression was fitted to assess the association between predictor variables and the outcome of interest.

Results: Out of the total $(1,179)$ participants, $60.5 \%$ (713) were willing to join the scheme. Households' occupation ( $\mathrm{AOR}=2.26 ; 95 \% \mathrm{CI}:=1.12-5.07)$, perceived good (AOR=2.21; $95 \% \mathrm{CI}:=1.53-3.21)$, and medium $(\mathrm{AOR}=1.44 ; 95 \% \mathrm{CI}=1.22-2.0)$ healthcare quality and richer wealth status $(\mathrm{AOR}=1.72 ; 95 \% \mathrm{CI}=1.08-2.73$ ) were associated with higher odds of willingness to join the scheme.

Conclusion: As The study revealed that level of willingness to join is lower compared to other studies. Therefore, social protection activities for the low-income population and enhancement of the capacity of health facilities are crucial.

Keywords: willingness to join, community-based health insurance, developing country, Ethiopia

\section{Introduction}

The majority of the health systems in many low- and middle-income countries (LMICs) heavily rely on household out of pocket (OOP) payments. ${ }^{1}$ However, household OOP payments have resulted in two negative consequences: a formidable barrier to demanding healthcare on one hand and household impoverishment on the other hand. ${ }^{1,2}$ Cognizant of this, Universal Health Coverage (UHC) looms large on policy agendas in LMICs. ${ }^{3}$ Universal Health Coverage promotes healthcare financing systems designed to give all people the required services of sufficient
Correspondence: Asmamaw Atnafu University of Gondar, PO Box 196,

Gondar, Ethiopia

Tel +25I-918776945

Email asme2002@gmail.com 
quality and ensure that the use of the services does not expose users to financial hardship. ${ }^{4,5}$ As a result, in the last three decades many of the LMICs have been struggling to introduce a prepaid healthcare financing system, such as micro or community-based health insurance (CBHI), to strengthen their healthcare financing system. ${ }^{6-8}$

The Ethiopian health system is challenged by a shortage of funds and heavily relies on foreign donations. ${ }^{9,10}$ The government expenditure on health is quite low compared to that of other low-income countries in East Africa. ${ }^{11,12}$ Pre-paid healthcare financing mechanisms are weak and only represent less than $1.25 \%$ of the healthcare expenditures. ${ }^{11,13}$ However, different insurance schemes have been endorsed in Ethiopia, such as Social Health Insurance (SHI) for formal sector employees and CBHI to reach and cover the very large agricultural sector and small informal sector in urban settings. ${ }^{14,15} \mathrm{CBHI}$ has been piloted in selected rural households of 13 districts since 2011 and expanded to additional districts in many of the regions as of $2013 .{ }^{14}$ Cluster participation was decided by general assemblies at woreda/cluster levels, while household membership is based on voluntary decisions. ${ }^{16}$ Essential health services at outpatient and inpatient levels are included as benefit packages for the CBHI. ${ }^{17}$ The level of CBHI enrollment is still considered low in northwest Ethiopia, and necessitates further investigation of the community acceptability of the CBHI.

Many studies have been conducted to identify factors associated with Willingness to Join (WTJ) or Willingness to Pay (WTP) for voluntary health insurance schemes, for instance, awareness and understanding of the concept of CBHI, trust in the scheme and scheme managers, perceived service quality, and demographic characteristics which influence the WTJ system. ${ }^{18}$ Additionally, lack of trust in the scheme, household size, and membership of town associations or unions were identified. ${ }^{19}$ Moreover, vulnerable groups in the household affected membership status. $^{20}$

Studies are very limited in Ethiopia, A study conducted in Southwest Ethiopia showed that the age of a household head, household size, educational status, wealth status, and annual incomes as some of the determinant factors. ${ }^{16}$ Another WTP study in northwest Ethiopia showed that household size, educational status, and wealth status of households were additional factors. ${ }^{21}$ Thus, most of the previous studies focused on the individual members and scheme related determinants, rather no sufficient finding is found with related to the association between availability of essential drugs in the health facility and willingness to CBHI enrollment. ${ }^{16,22,23}$

Moreover, previous studies utilized low sample size, which requires additional studies using relatively large sample size. Therefore, the current study attempted to address some of the limitations of the previous studies by increasing the samples and utilize factors related to the supply side, thereby enhancing the representativeness and the statistical power of the work. Thus, we intended to investigate the level of WTJ in CBHI and associated factors in northwest Ethiopia.

\section{Methods}

\section{Study Site, Sampling, and Design}

A community-based cross-sectional study was conducted in the Amhara Regional State in northwest Ethiopia. A sample of 1,179 households without CBHI membership was calculated by the single proportion formula. A twostage sampling technique was used to select participant households from 15 selected clusters. The details of the study site, sampling, and design are found in a former publication by Atafu and Kwon. ${ }^{10}$

\section{Variables and Measurements}

The dependent variable of the study was Willingness to Join (WTJ) CBHI. It was measured based on respondent's willingness to join CBHI or not. Accordingly, if the respondent responded as "yes", we considered them as "willing to join", if the respondent responded as "no" we considered "not willing to join". Whereas the predictor variables sociodemographic, wealth status, perceived quality of health, occupation, household size, local credit membership, religious membership, and availability essential drugs, which includes oral rehydration salt (ORS) and laboratory equipment that could be used for laboratory analysis and other.

Wealth index is based on the assumption that wealth or economic status is a latent variable. We assume that economic status is the common factor behind the ownership of the assets, such that household economic status explains the maximum variance and covariance in the asset variables. It was calculated as an index based on the consumer goods and household characteristics. These scores were derived using principal component analysis and ranked into five (poorest, poorer, middle, richer, and richest). The wealth quintiles are expressed in terms of quintiles of individuals in the population rather than quintiles of 
individuals at risk for anyone's health or population indicator.

\section{Data Analysis and Management}

Following the completion of the necessary coding, data were entered into Stata version 14 (STATA/SE 14, StataCorp LP, 4905 Lakeway Drive, College Station, TX 77845). Then, using the software, cleaning, recoding, and analysis were carried out. The analysis was performed at the household level because enrollment in the Ethiopian $\mathrm{CBHI}$ is often done that way. WTJ the CBHI, the outcome variable, was treated as a binary outcome (the number "1" was recorded for "willingness to join", and zero "0" for "not willing"). In order to assess the associations between the predictor variables and the outcome of interest, the bivariable and multivariable logistic regression was fitted.

Odds ratios with the corresponding 95\% confidence intervals and $P$-value less than 0.05 were reported to evaluate the associations between independent variables and WTJ CBHI.

\section{Results}

\section{Descriptive Findings on Willingness to Join Community-Based Health Insurance (Table I)}

Out of the total 1,179 participants, 60.5\% (713) were WTJ the CBHI. The mean age of the respondents in the WTJ group households was significantly lower $(P=0.00)$ than that of the unwilling group. The WTJ CBHI participants had a significantly higher perceived healthcare quality $(P=0.00)$ than the unwilling group. The willing group included a higher proportion of richer households compared to the unwilling $(P=0.01)$. The proportion of under- 5 children and elderly above age 64 was significantly higher in the willing group than the unwilling. However, there were no significant differences in local solidarity and religious participation in the two groups. The WTJ group had a significantly higher proportion of household members with official positions in the area $(P=0.00)$. The availability of blood hematology analyzers, and oral rehydration salt (ORS), as well as blood glucose tests were found to be significant factors that influence a willingness level to join community-based health insurance $(P=0.00)$.

\section{Determinants of WTJ Community-Based Health Insurance (Table 2)}

The logistic regression analysis result in Table 2 showed that household heads in the age group of 41-50 and above
50 years had $48 \%$ and $52 \%$ lower percent of willingness to join the insurance compared to participants in the age group of $18-30$ years $(\mathrm{OR}=0.52 ; 0.34-0.81),(\mathrm{OR}=0.48$; $0.30-0.76)$, respectively. Household heads with secondary school and above educational status showed a $57 \%$ lower percent of WTJ compared to illiterate heads $(\mathrm{OR}=0.43$, $0.22-0.85)$. Merchants had nearly 2.3 -times more odds of willingness to join than farmers $(\mathrm{OR}=2.26 ; 1.12-5.07)$. Household heads with a good and medium perceived healthcare quality had 2.21- and 1.44-times higher odds of willingness to join CBHI compared to respondents with poor perceived healthare quality $(\mathrm{AOR}=2.21 ; 1.53$ -3.21; AOR=1.44; 1.22-2.08), respectively. Respondents in the richer wealth status had 1.7-times higher odd of willingness to join $\mathrm{CBHI}$ compared to respondents in the poorest wealth status $(\mathrm{OR}=1.72 ; 1.08-2.73)$. Moreover, households with a pregnant woman member showed 1.7times higher odds of joining than a household without such women $(\mathrm{OR}=1.70 ; 1.24-2.95)$. Additionally, membership in a local credit association as social capital had 1.4-times higher odds of willingness to join $(\mathrm{OR}=1.43$; 1.13-1.98). Moreover, households with at least one member in an official position showed nearly 1.6-times higher odds of willingness to join compared to those without a member in such a position $(\mathrm{OR}=1.56 ; 1.08-2.25)$. Additionally, health facility-related factors showed a significant relationship with willingness to join. The availability of some essential drugs, like oral rehydration salt (ORS) $\quad(\mathrm{AOR}=1.67 ; 95 \% \quad \mathrm{CI}=1.50-3.02)$, laboratory equipment (hematological analyzer) $(\mathrm{OR}=2.02 ; 1.22$ 3.31 ), and blood glucose tests (AOR $=1.38 ; 95 \%$ $\mathrm{CI}=1.11-1.9)$ in health centers increased the odds of willingness to join.

\section{Discussion}

In this study the level of willingness to join CBHI was $60.5 \%$, less than that of a study finding ${ }^{16}$ from southwest Ethiopia where $78 \%$ of the study participants were willing to join. Moreover, our finding is also lower than that of a study in Fogera district in northwest Ethiopia, ${ }^{21}$ which reported a willingness rate of $80 \%$. The reason could be attributed to variations in study period and participants. Studies mentioned were basically in a rural community in the early piloting period of CBHI, while the current study was conducted in the expansion period at which communities may have different pieces of information and exposure through time. Moreover, a recent study showed that CBHI members complained about the service provided by 
Table I Descriptive Results WTJ CBHI in Northwest Ethiopia, 2017

\begin{tabular}{|c|c|c|c|c|c|}
\hline \multirow[t]{2}{*}{ Predictor Variables } & & \multicolumn{3}{|l|}{ WTJ CBHI } & \multirow[t]{2}{*}{$P$-value } \\
\hline & & Yes, N (\%) & No, $\mathbf{N}(\%)$ & Total, $\mathbf{N}(\%)$ & \\
\hline & & $713(60.5)$ & $466(39.5)$ & I,I $79(100)$ & \\
\hline Sex & $\begin{array}{l}\text { Male } \\
\text { Female }\end{array}$ & $\begin{array}{l}497(60.8) \\
216(59.7)\end{array}$ & $\begin{array}{l}320(39.2) \\
146(40.3)\end{array}$ & $\begin{array}{l}817(69.3) \\
362(30.7)\end{array}$ & 0.70 \\
\hline Age & & $\begin{array}{l}\text { Mean }=41.4 \text { years } S D=13.6 \\
\text { years }\end{array}$ & $\begin{array}{l}\text { Mean }=45.7 \text { years } S D=14.9 \\
\text { years }\end{array}$ & $\begin{array}{l}\text { Mean }=44.5 \text { years } \\
S D=13.8 \text { years }\end{array}$ & 0.00 \\
\hline Residence & $\begin{array}{l}\text { Rural } \\
\text { Urban }\end{array}$ & $\begin{array}{l}648(90.9) \\
65(9.1)\end{array}$ & $\begin{array}{l}414(88.8) \\
52(11.2)\end{array}$ & $\begin{array}{l}1,062(90.1) \\
117(9.9)\end{array}$ & 0.25 \\
\hline Education & $\begin{array}{l}\text { Illiterate/no } \\
\text { Read \& write } \\
\text { Elementary } \\
(\mathrm{I}-4) \\
\text { Elementary } \\
(5-8) \\
\text { Secondary } \\
\text { School }\end{array}$ & $\begin{array}{l}389(54.6) \\
189(26.5) \\
71(10.0) \\
38(5.3) \\
26(3.7)\end{array}$ & $\begin{array}{l}267(57.4) \\
97(20.8) \\
49(10.5) \\
26(5.6) \\
27(5.8)\end{array}$ & $\begin{array}{l}656(55.6) \\
286(24.3) \\
120(10.2) \\
64(5.4) \\
53(4.5)\end{array}$ & 0.12 \\
\hline Marital Status & $\begin{array}{l}\text { Single } \\
\text { Married } \\
\text { Divorced } \\
\text { Widowed }\end{array}$ & $\begin{array}{l}30(4.2) \\
580(81.4) \\
64(9.0) \\
39(5.5)\end{array}$ & $\begin{array}{l}22(4.7) \\
355(76.2) \\
50(10.7) \\
39(8.4)\end{array}$ & $\begin{array}{l}52(4.4) \\
935(79.3) \\
114(9.7) \\
78(6.6)\end{array}$ & 0.13 \\
\hline Occupation & $\begin{array}{l}\text { Farmer } \\
\text { Merchant } \\
\text { Day laborer } \\
\text { Petty trader }\end{array}$ & $\begin{array}{l}620(87.0) \\
34(4.8) \\
17(2.4) \\
42(5.9)\end{array}$ & $\begin{array}{l}391(83.9) \\
11(2.4) \\
24(5.2) \\
40(8.6)\end{array}$ & $\begin{array}{l}I, 011(85.8) \\
45(3.8) \\
4 I(3.5) \\
82(7.0)\end{array}$ & 0.00 \\
\hline Self-rated Health & $\begin{array}{l}\text { Poor } \\
\text { Medium } \\
\text { Good }\end{array}$ & $\begin{array}{l}28(3.9) \\
203(28.5) \\
482(67.6)\end{array}$ & $\begin{array}{l}41(8.8) \\
117(25.1) \\
308(66.1)\end{array}$ & $\begin{array}{l}69(5.9) \\
320(27.1) \\
790(67.0)\end{array}$ & 0.00 \\
\hline Perceived quality $\mathrm{Hs}$ & $\begin{array}{l}\text { Poor } \\
\text { Medium } \\
\text { Good }\end{array}$ & $\begin{array}{l}115(16.1) \\
196(27.5) \\
402(56.4)\end{array}$ & $\begin{array}{l}\text { II } 2(24.0) \\
\text { I } 48(3 \mathrm{I} .8) \\
206(44.2)\end{array}$ & $\begin{array}{l}227(19.3) \\
344(29.2) \\
608(51.6)\end{array}$ & 0.00 \\
\hline Household size & & Mean $=4.5 \mathrm{SD}=1.92$ & Mean=4.5 SD 1.96 & Mean $=4.5 \mathrm{SD}=2.0$ & 0.68 \\
\hline Chronic disease & $\begin{array}{l}\text { No } \\
\text { Yes }\end{array}$ & $\begin{array}{l}596(83.6) \\
117(16.4)\end{array}$ & $\begin{array}{l}386(82.8) \\
80(17.2)\end{array}$ & $\begin{array}{l}982(83.3) \\
197(16.7)\end{array}$ & 0.73 \\
\hline Wealth Index & $\begin{array}{l}\text { Poorest } \\
\text { Poorer } \\
\text { Middle } \\
\text { Richer } \\
\text { Richest }\end{array}$ & $\begin{array}{l}145(20.4) \\
166(23.4) \\
145(20.4) \\
133(18.7) \\
122(17.2)\end{array}$ & $\begin{array}{l}128(27.6) \\
78(16.8) \\
97(20.9) \\
82(17.8) \\
79(17.0)\end{array}$ & $\begin{array}{l}273(23.2) \\
244(20.8) \\
242(20.6) \\
215(18.3) \\
20 I \quad 17.1)\end{array}$ & 0.01 \\
\hline Pregnant & $\begin{array}{l}\text { No } \\
\text { Yes }\end{array}$ & $\begin{array}{l}641(90.2) \\
70(9.9)\end{array}$ & $\begin{array}{l}440(94.6) \\
25(5.4)\end{array}$ & $\begin{array}{l}1,081(91.9) \\
95(8.1)\end{array}$ & 0.00 \\
\hline Under-five & $\begin{array}{l}\text { No } \\
\text { Yes }\end{array}$ & $\begin{array}{l}429(60.2) \\
284(39.8)\end{array}$ & $\begin{array}{l}324(69.5) \\
142(30.5)\end{array}$ & $\begin{array}{l}753(63.9) \\
426(36.3)\end{array}$ & 0.00 \\
\hline
\end{tabular}

(Continued) 
Table I (Continued).

\begin{tabular}{|c|c|c|c|c|c|}
\hline \multirow[t]{2}{*}{ Predictor Variables } & & \multicolumn{3}{|l|}{ WTJ CBHI } & \multirow[t]{2}{*}{$P$-value } \\
\hline & & Yes, N (\%) & No, N (\%) & Total, N (\%) & \\
\hline \multirow{2}{*}{$\begin{array}{l}\text { Enrolled in solidarity } \\
\text { group }\end{array}$} & No & $90(12.6)$ & $55(11.8)$ & $145(12.3)$ & \\
\hline & Yes & $623(87.4)$ & $4 I I(88.2)$ & $\mathrm{I}, 034(87.7)$ & 0.67 \\
\hline \multirow{2}{*}{$\begin{array}{l}\text { Local credit } \\
\text { membership }\end{array}$} & No & $356(49.9)$ & $275(59.0)$ & 63I (53.5) & \\
\hline & Yes & $357(50.1)$ & $191(41.0)$ & $548(46.5)$ & 0.00 \\
\hline \multirow{2}{*}{$\begin{array}{l}\text { Religious group } \\
\text { membership }\end{array}$} & No & $124(17.4)$ & $85(18.2)$ & $209(17.7)$ & \\
\hline & Yes & $589(82.6)$ & $381(81.8)$ & $970(82.3)$ & 0.70 \\
\hline \multirow[t]{2}{*}{ Saving account } & No & $382(53.6)$ & $267(57.3)$ & $649(55.1)$ & \\
\hline & Yes & $331(46.4)$ & $199(42.7)$ & $530(45.0)$ & 0.20 \\
\hline \multirow[t]{2}{*}{ Official position holder } & No & $562(78.8)$ & $40 \mathrm{I}(86.0)$ & $963(8 \mathrm{I} .7)$ & \\
\hline & Yes & $|5|(2 \mid .2)$ & $65(13.9)$ & $216(18.3)$ & 0.00 \\
\hline \multirow[t]{2}{*}{ Availability of ORS } & No & 149 (20.9) & $60(12.9)$ & $209(17.7)$ & \\
\hline & Yes & $564(79.1)$ & $406(87.1)$ & $970(82.3)$ & 0.00 \\
\hline \multirow[t]{2}{*}{ Analyzer hematology } & No & $488(68.4)$ & $376(80.7)$ & $864(73.3)$ & \\
\hline & Yes & $225(31.6)$ & $90(19.3)$ & $315(26.7)$ & 0.00 \\
\hline \multirow[t]{2}{*}{ Blood glucose test } & No & $157(22.0)$ & $122(26.2)$ & $279(23.7)$ & \\
\hline & Yes & $556(78.0)$ & $344(73.8)$ & $900(76.3)$ & 0.05 \\
\hline
\end{tabular}

Abbreviation: ORS, oral rehydration salt.

a CBHI contracted health facility, which could be one reason for not being willing. ${ }^{10}$

In this study, educational status has a significantly negative association with willingness to join in CBHI. This result is different from the findings of enrollment studies in Kenya, ${ }^{1}$ Bangladesh, ${ }^{24}$ Vietnam, ${ }^{25}$ India, ${ }^{26}$ Burkina Faso, ${ }^{27}$ and Lao PDR, ${ }^{28}$ which indicate positive relationships between the educational status and health insurance enrollment. The disagreement could reflect previous experiences and quality of services. Members of CBHI are supposed to have contract agreements, mainly with public health posts and health centers. Services at this point are blamed for low quality, which could deter the educated people from joining the $\mathrm{CBHI}$, and choosing to get health services from other providers. ${ }^{29}$

This study demonstrated a negative relationship between the age of household head and willingness to join the CBHI, which is in line with a WTJ study in Ethiopia. ${ }^{16}$ However, this result was inconsistent with findings reported from Kenya, Vietnam, India, and Cameroon, 1,25,26,30,31 which revealed that as the age of household heads increased the demand for health insurance increased. This could also be justified by the low benefit package of $\mathrm{CBHI}$ and the quality of services accessed.

The multivariable logistic regression showed that occupation of household heads have a positive relationship with willingness to join $\mathrm{CBHI}$, for example merchants have nearly 2.3-times higher odds of willingness to join $\mathrm{CBHI}$ than farmers. The finding is in line with that of another study in Ethiopia. ${ }^{32}$ This could be justified by the fact that merchants may have some kind of daily income which enables them to pay insurance premiums easily. Farmers usually do not have permanent incomes to meet such requirements. Moreover, merchants may have frequent communication with many peoples which helps them to share ideas and enable them to know about the benefits of insurance.

In this study, perceived quality of health services provided by public health facilities have a positive and significant association with WTJ. Study results in Nigeria, Lao PDR, and Burkina Faso ${ }^{28,33,34}$ also showed that perceived quality of healthcare services encouraged participation in CBHI. 
Table 2 Logistic Regression Results: Probability of WTJ CBHI in Northwest Ethiopia

\begin{tabular}{|c|c|c|c|c|}
\hline \multicolumn{2}{|l|}{ Independent Variables } & \multirow{2}{*}{$\begin{array}{l}\text { COR }(95 \% \mathrm{CI}) \\
\mathrm{I} \\
0.95(0.74-1.23)\end{array}$} & \multirow{2}{*}{$\begin{array}{l}\text { AOR }(95 \% \mathrm{CI}) \\
\mathrm{I} \\
\mathrm{I} .02(0.72-1.43)\end{array}$} & \multirow{2}{*}{$\begin{array}{l}P \text {-value } \\
0.92\end{array}$} \\
\hline Sex & $\begin{array}{l}\text { Male } \\
\text { Female }\end{array}$ & & & \\
\hline Age & $\begin{array}{l}18-30 \\
31-40 \\
41-50 \\
50+\end{array}$ & $\begin{array}{l}\text { I } \\
0.88(0.626-1.23) \\
0.65(0.459-0.92) \\
0.515(0.373-0.7 I)\end{array}$ & $\begin{array}{l}\text { I } \\
0.79(0.53-I .16) \\
0.52(0.34-0.81) \\
0.48(0.31-0.76)\end{array}$ & $\begin{array}{l}0.23 \\
0.00 \\
0.00\end{array}$ \\
\hline Residence & $\begin{array}{l}\text { Rural } \\
\text { Urban }\end{array}$ & $\begin{array}{l}\text { I } \\
0.79(0.543-1.17)\end{array}$ & $\begin{array}{l}\text { I } \\
0.92(0.47-1.79)\end{array}$ & 0.82 \\
\hline Education & $\begin{array}{l}\text { Illiterate/no } \\
\text { Read \& write } \\
\text { Elementary (I-4) } \\
\text { Elementary (5-8) } \\
\text { Secondary School }\end{array}$ & $\begin{array}{l}\text { I } \\
\text { I.34 (I.00-I.78) } \\
0.99(0.67-1.48) \\
1.00(0.59-1.69) \\
0.66(0.37-1.16)\end{array}$ & $\begin{array}{l}\text { I } \\
\text { I.23 }(0.89-|.7|) \\
0.80(0.5 I-1.25) \\
0.73(0.23-0.85) \\
0.43(0.23-0.85)\end{array}$ & $\begin{array}{l}0.21 \\
0.33 \\
0.31 \\
0.01\end{array}$ \\
\hline Marital Status & $\begin{array}{l}\text { Single } \\
\text { Married } \\
\text { Divorce } \\
\text { Widowed }\end{array}$ & $\begin{array}{l}\text { I } \\
1.19(0.68-2.11) \\
0.94(0.48-1.82) \\
0.73(0.36-1.49)\end{array}$ & $\begin{array}{l}\text { I } \\
1.10(0.61-1.98) \\
0.89(0.44-1.80) \\
0.83(0.39-1.76)\end{array}$ & $\begin{array}{l}0.76 \\
0.75 \\
0.63\end{array}$ \\
\hline Occupation & $\begin{array}{l}\text { Farmer } \\
\text { Merchant } \\
\text { Day laborer } \\
\text { Petty trader }\end{array}$ & $\begin{array}{l}\text { I } \\
\text { I.95 (0.98-3.89) } \\
0.45(0.24-0.84) \\
0.66(0.42-1.04)\end{array}$ & $\begin{array}{l}I \\
2.26(1.12-5.07) \\
0.42(0.20-0.91) \\
0.81(0.41-1.62)\end{array}$ & $\begin{array}{l}0.04 \\
0.02 \\
0.56\end{array}$ \\
\hline Perceived Quality Hs & $\begin{array}{l}\text { Poor } \\
\text { Medium } \\
\text { Good }\end{array}$ & $\begin{array}{l}\mathrm{I} \\
\mathrm{I} .29(0.92-1.8 \mathrm{I}) \\
\mathrm{I} .90(1.39-2.59)\end{array}$ & $\begin{array}{l}\text { I } \\
\text { I.44 (I.22-2.08) } \\
2.21(1.53-3.21)\end{array}$ & $\begin{array}{l}0.05 \\
0.00\end{array}$ \\
\hline $\mathrm{HHZ}$ & $\begin{array}{l}>5 \\
<5\end{array}$ & $\begin{array}{l}\text { I } \\
0.95(0.74-1.22)\end{array}$ & $\begin{array}{l}\text { I } \\
0.96(0.72-1.29)\end{array}$ & 0.79 \\
\hline Chronic disease & $\begin{array}{l}\text { No } \\
\text { yes }\end{array}$ & $\begin{array}{l}\text { I } \\
0.95(0.69-1.29)\end{array}$ & $\begin{array}{l}\text { I } \\
1.19(0.84-1.71)\end{array}$ & 0.31 \\
\hline Wealth Index & $\begin{array}{l}\text { Poorest } \\
\text { Poorer } \\
\text { Middle } \\
\text { Richer } \\
\text { Richest }\end{array}$ & $\begin{array}{l}\text { I } \\
1.89(1.31-2.69) \\
1.32(0.93-1.87) \\
1.43(0.99-2.06) \\
1.36(0.94-1.97)\end{array}$ & $\begin{array}{l}\text { I } \\
1.96(1.25-3.05) \\
1.33(0.86-2.05) \\
1.72(1.08-2.73) \\
1.27(0.78-2.07)\end{array}$ & $\begin{array}{l}0.00 \\
0.19 \\
0.02 \\
0.33\end{array}$ \\
\hline Pregnant & $\begin{array}{l}\text { No } \\
\text { Yes }\end{array}$ & $1.92(1.19-3.08)$ & $\begin{array}{l}\text { I } \\
1.70(1.25-2.95)\end{array}$ & 0.05 \\
\hline Under-five & $\begin{array}{l}\text { No } \\
\text { Yes }\end{array}$ & $\begin{array}{l}1 \\
1.15(1.17-1.94)\end{array}$ & $\begin{array}{l}\text { I } \\
\text { I.06 (0.78-I.44) }\end{array}$ & 0.69 \\
\hline Elderly & $\begin{array}{l}\text { No } \\
\text { Yes }\end{array}$ & $\begin{array}{l}\text { I } \\
0.59(0.39-0.87)\end{array}$ & $\begin{array}{l}\text { I } \\
0.78(0.48-1.24)\end{array}$ & 0.29 \\
\hline Local credit membership & $\begin{array}{l}\text { No } \\
\text { Yes }\end{array}$ & $\begin{array}{l}\text { Ref } \\
1.44(1.14-1.83)\end{array}$ & $\begin{array}{l}\text { I } \\
1.43(1.13-1.98)\end{array}$ & 0.03 \\
\hline Religious group membership & $\begin{array}{l}\text { No } \\
\text { Yes }\end{array}$ & $\begin{array}{l}\text { I } \\
\text { I.05 (0.78-1.44) }\end{array}$ & $\begin{array}{l}\text { I } \\
1.12(0.74-1.68)\end{array}$ & 0.60 \\
\hline
\end{tabular}

(Continued) 
Table 2 (Continued).

\begin{tabular}{|c|c|c|c|c|}
\hline \multicolumn{2}{|l|}{ Independent Variables } & \multirow{2}{*}{$\begin{array}{l}\text { COR }(95 \% \mathrm{CI}) \\
\mathrm{I} \\
\mathrm{I} .16(0.92-1.47)\end{array}$} & \multirow{2}{*}{$\begin{array}{l}\text { AOR }(95 \% \mathrm{Cl}) \\
\mathrm{I} \\
0.84(0.62-1.14)\end{array}$} & \multirow{2}{*}{$\begin{array}{l}P \text {-value } \\
0.26\end{array}$} \\
\hline Saving account & $\begin{array}{l}\text { No } \\
\text { Yes }\end{array}$ & & & \\
\hline Official position holder & $\begin{array}{l}\text { No } \\
\text { Yes }\end{array}$ & $\begin{array}{l}\text { I } \\
1.66(1.21-2.28)\end{array}$ & I.56 (I.08-2.25) & 0.02 \\
\hline Availability of ORS & $\begin{array}{l}\text { No } \\
\text { Yes }\end{array}$ & $\begin{array}{l}\text { I } \\
0.56(0.40-0.77)\end{array}$ & I.67 (I.5I-3.03) & 0.05 \\
\hline Analyzer hematology & $\begin{array}{l}\text { No } \\
\text { Yes }\end{array}$ & $\begin{array}{l}\text { I } \\
1.93(1.46-2.55)\end{array}$ & $\begin{array}{l}\text { I } \\
2.02(I .23-3.3 I)\end{array}$ & 0.01 \\
\hline Blood glucose test availability & $\begin{array}{l}\text { No } \\
\text { Yes }\end{array}$ & $\begin{array}{l}\text { I } \\
1.26(0.96-1.65)\end{array}$ & $\begin{array}{l}\text { I } \\
1.38(1.11-1.99)\end{array}$ & 0.04 \\
\hline $\begin{array}{l}\text { cons } \\
\text { Number of observations } \\
\text { Wald chi }{ }^{2} \\
\text { Prob>chi }\end{array}$ & & & $\begin{array}{l}0.36(0.12-0.67) \\
1172 \\
108.56 \\
0.00\end{array}$ & 0.05 \\
\hline
\end{tabular}

Notes: Outcome variable is households willingness to join (WTJ) CBHI in 2017, explanatory variables are at household and health facility level.

Abbreviations: AOR, adjusted odds ratio; $\mathrm{Cl}$, confidence intervals; $\mathrm{COR}$, crude odds ratio; $\mathrm{HHZ}$, household size.

In our study, household wealth status has a positive association with WTJ insurance. This finding is in line with those studies in Ethiopia ${ }^{16}$ and Uganda ${ }^{35,36}$ which indicate that wealthier households are more likely to join CBHI compared to poorer ones.

Moreover, households with pregnant women members showed 1.7-times higher odds of joining $\mathrm{CBHI}(\mathrm{OR}=1.70$; 1.24-2.95). This finding is justifying that households with vulnerable members are willing to be members, because such households imagine more uncertainty which makes them more WTJ than households without vulnerable members.

Additionally, prior participation in local credit associations also shows more odds of participation in health insurance. A study in Cameroon and Senegal ${ }^{30,37,38}$ also found that households more involved in informal associations were more willing to join and pay for health insurances.

The other essential finding of the study is the impact of the availability of services such as blood glucose tests in the health facilities on participation in health insurances. This finding is in line with those of studies conducted during the pilot implementation of CBHI in Ethiopia, Lao PDR, and Senegal. ${ }^{28,38,39}$ Lack of services and poorquality care remains a source of unhappiness for both members and non-members in many developing countries.

The rate of willingness to join CBHI is low compared to those of previous studies. Moreover, many demand and supply side factors influence the willingness to join $\mathrm{CBHI}$ in the study area. According to the findings, multilayered policy interventions are essential. Social protection activities are important to improve the income of households, thereby to increase community WTJ CBHI. Policy interventions that enhance the capacity of health facilities to provide quality health services are relevant.

\section{Limitations}

The cross-sectional nature of this study is the first limitation which might challenge the inference of causation. However, the findings can be used as input for policymakers before the nationwide roll-out of $\mathrm{CBHI}$ in Ethiopia.

\section{Data Sharing Statements}

All the data supporting the findings are within the manuscript. Additional detailed information and raw data are available from the corresponding author on reasonable request.

\section{Acknowledgments}

The authors would like to acknowledge the study participants and data collectors for their kind participation.

\section{Author Contributions}

All authors made a significant contribution to the work reported, whether that is in the conception, study design, 
execution, acquisition of data, analysis and interpretation, or in all these areas; took part in drafting, revising, or critically reviewing the article; gave final approval of the version to be published; have agreed on the journal to which the article has been submitted; and agree to be accountable for all aspects of the work.

\section{Disclosure}

The authors report no conflicts of interest in this work.

\section{References}

1. Kiplagat I, Muriithi M, Kioko U. Determinants of Health Insurance Choice in Kenya. Eur Sci J. 2013;9:13.

2. Ansah EK, Narh-Bana S, Asiamah S, et al. Effect of removing direct payment for health care on utilisation and health outcomes in Ghanaian children: a randomised controlled trial. PLoS Med. 2009;6(1):e1000007. doi:10.1371/journal.pmed. 1000007

3. Raza W, van de Poel E, Panda P. Analyses of enrolment, dropout and effectiveness of RSBY in northern rural India. 2016.

4. Kutzin J. Health financing for universal coverage and health system performance: concepts and implications for policy. Bull World Health Organ. 2013;91(8):602-611.

5. World Health Organaization. The World Health Organaization Report, Health System Financing; 2010.

6. Dekker M. Sustainability and resourcefulness: support networks during periods of stress. World Dev. 2004;32(10):1735-1751. doi:10.1016/j.worlddev.2004.06.002

7. Dekker M, Health Insurance WA. Other Risk-Coping Strategies in Uganda: the Case of Microcare Insurance Ltd. World Dev. 2010;38 (3):369-378. doi:10.1016/j.worlddev.2009.09.004

8. Yilma Z, Mebratie A, Sparrow R, Dekker M, Alemu G, Bedi AS. Impact of Ethiopia's Community Based Health Insurance on Household Economic Welfare. World Bank Econ Rev. 2015;29 (suppl_1):S164-S173. doi:10.1093/wber/lhv009

9. Asmamaw Atnafu Ayalneh DMF, Lee TJ. Inequalities in health care utilization for common childhood illnesses in Ethiopia: evidence from the 2011 Ethiopian Demographic and Health Survey. Int J Equity Health. 2017;124.

10. Atafu A, Kwon S. Adverse selection and supply-side factors in the enrollment in community-based health insurance in Northwest Ethiopia: A mixed methodology. Int $J$ Health Plann Manage. 2018;33(4):902-914.

11. World Health Organaization. Global Health Observatory data repository Health expenditure ratios, by country, 1995-2014; 2016; http:// apps.who.int/gho/data/node.main.75. Accessed July 19, $2017 .$.

12. Federal Ministry of Ethiopia. Health Sector TRansformation Plan; 2015.

13. Ministry of Health Ethiopia. ETHIOPIAS HOUSEHOLD HEALTH SERVICES UTILIZATION and EXPENDITURE SURVEY BRIEFING NOTES; 2014.

14. Ethiopian Health Insurance Agency. Evaluation of Community-Based Health Insurance Pilot Schemes in Ethiopia: Final Report. Addis Ababa,; 2015.

15. Agago TA, Woldie M, Ololo S. Willingness to join and pay for the newly proposed social health insurance among teachers in Wolaita Sodo Town, South Ethiopia. Ethiop J Health Sci. 2014;24(3):195202. doi:10.4314/ejhs.v24i3.2

16. Haile M, Ololo S, Megersa B. Willingness to join community-based health insurance among rural households of Debub Bench District, Bench Maji Zone, Southwest Ethiopia. BMC Public Health. 2014;14 (1):591. doi:10.1186/1471-2458-14-591
17. Governance HCFa. Ethiopia's Community-Based Health Insurance: A Step on the Road to Universal Health Coverage. USAID from the American People; 2014.

18. Fadlallah R, El-Jardali F, Hemadi N, et al. Barriers and facilitators to implementation, uptake and sustainability of communitybased health insurance schemes in lowand middle-income countries: a systematic review. Int J Equity Health. 2018;17(1). doi:10.1186/s12939-018-0721-4

19. Oriakhi H, Onemolease E. Determinants of rural household's willingness to participate in community based health insurance scheme in Edo State, Nigeria. Stud Ethno Med. 2012;6(2):95-102. doi:10.1080/ 09735070.2012 .11886425

20. Macha J, Kuwawenaruwa A, Makawia S, Mtei G, Borghi J. Determinants of community health fund membership in Tanzania: a mixed methods analysis. BMC Health Serv Res. 2014;14(1):1. doi:10.1186/s12913-014-0538-9

21. Kebede A, Gebreslassie M, Yitayal M. Willingness to pay for community based health insurance among households in the rural community of Fogera District, north West Ethiopia. Int J Econ Finance Manag Sci. 2014;2(4):263-269. doi:10.11648/j.ijefm.20140204.15

22. Minyihun A, Gebregziabher MG, Gelaw YA. Willingness to pay for community-based health insurance and associated factors among rural households of Bugna District, Northeast Ethiopia. BMC Res Notes. 2019;12(1):55. doi:10.1186/s13104-019-4091-9

23. Nageso D, Tefera K, Gutema K. Enrollment in community based health insurance program and the associated factors among households in Boricha district, Sidama Zone, Southern Ethiopia; a cross-sectional study. PLoS One. 2020;15(6):e0234028. doi:10.1371/ journal.pone. 0234028

24. Ahmed S, Hoque ME, Sarker AR, et al. Willingness-to-Pay for Community-Based Health Insurance among Informal Workers in Urban Bangladesh. PLoS One. 2016;11(2):2. doi:10.1371/journal. pone. 0148211

25. Lofgren C, Thanh NX, Chuc NT, Emmelin A, Lindholm L. People's willingness to pay for health insurance in rural Vietnam. Cost Effect Resource Allocation. 2008;6(1):16. doi:10.1186/1478-7547-6-16

26. Panda P, Chakraborty A, Dror DM, Bedi AS. Enrolment in community-based health insurance schemes in rural Bihar and Uttar Pradesh, India. Health Policy Plan. 2014;29(8):960-974. doi:10.1093/heapol/ czt077

27. De Allegri M, Kouyate B, Becher H, et al. Understanding enrolment on community health insurance on sub-Saharan Africa: a populationbased case-control study on rural Burkina Faso. Bull World Health Organ. 2006;84(11):852-858. doi:10.2471/BLT.06.031336

28. Alkenbrack S, Jacobs B, Lindelow M. Achieving universal health coverage through voluntary insurance: what can we learn from the experience of Lao PDR? BMC Health Serv Res. 2013;13(1):1.

29. Atafu A, Kwon S. Adverse selection and supply-side factors in the enrollment in community-based health insurance in Northwest Ethiopia: A mixed methodology. Int $J$ Health Plann Manage. 2018;33(4):902-914. doi:10.1002/hpm.2546

30. Donfouet HPP, Mahieu P-A ME. Using respondents' uncertainty scores to mitigate hypothetical bias in community-based health insurance studies. Eur J Health Econ. 2013;14(2):277-285. doi:10.1007/ s10198-011-0369-0

31. Adebayo EF, Uthman OA, Wiysonge CS, Stern EA, Lamont KT, Ataguba JE. A systematic review of factors that affect uptake of community-based health insurance in low-income and middle-income countries. BMC Health Serv Res. 2015;15(1):543.

32. Kebede A, Gebreslassie M, Yitayal M. Willingness to pay for community based health insurance among households in the rural community of Fogera District, North West Ethiopia. Int J Econ Finance Manag Sci. 2014;2326-9553.

33. Ataguba JE. Community Health Insurance Scheme as a Viable Option for Rural Population in Nigeria. Centre for the Study of African Economies (CSAE), Department of Economics, University of Oxford; 2008. 
34. Dong H, De Allegri M, Gnawali D, Souares A, Sauerborn R. Dropout analysis of community-based health insurance membership at Nouna, Burkina Faso. Health Policy Plan. 2009;92(2-3):174-179.

35. Basaza R, Criel B. Low enrolment in Ugandan community health insurance schemes: underlying causes and policy implications. $B M C$ Health Serv Res. 2007;7.

36. Basaza R, Criel B, Van der Stuyft P. Van der Stuyft P. Community health insurance in Uganda: why does enrolment remain low? A view from beneath. Health Policy Plan. 2008;87(2):172-184. doi:10.1016/ j.healthpol.2007.12.008

37. Binam J, Nkama A, Nkenda R. Estimating the willingness to pay for community health prepayment schemes in rural area: A case study of the use of contingent valuation surveys in central Cameroon (Yaounde, Institute of Agricultural Research for Development). 2004.
38. Mladovsky P. Why do people drop out of community-based health insurance? Findings from an exploratory household survey in Senegal. Soc Sci Med. 2014;107:78-88. doi:10.1016/j.socscimed. 2014.02.008

39. Mebratie AD, Sparrow R, Yilma Z, Abebaw D, Alemu G, Bedi A. Impact of Ethiopian pilot community-based health insurance scheme on health-care utilisation: a household panel data analysis. Lancet. 2013;381:92. doi:10.1016/S0140-6736(13)61346-X

\section{Publish your work in this journal}

ClinicoEconomics and Outcomes Research is an international, peerreviewed open-access journal focusing on Health Technology Assessment, Pharmacoeconomics and Outcomes Research in the areas of diagnosis, medical devices, and clinical, surgical and pharmacological intervention. The economic impact of health policy and health systems organization also constitute important areas of coverage. The manuscript management system is completely online and includes a very quick and fair peer-review system, which is all easy to use. Visit http://www.dovepress.com/testimonials.php to read real quotes from published authors. 